nina.govedar@flf.unibl.org

Универзитет у Бањој Луци

Филолошки факултет

Универзитет у Источном Сарајеву

Филозофски факултет

\title{
ЗБОРНИК РАДОВА СА МЕЪУНАРОДНЕ НАУЧНЕ КОНФЕРЕНЦИЈЕ КОМИСИЈЕ ЗА НАСТАВУ СЛОВЕНСКИХ ЈЕЗИКА И КЊИЖЕВНОСТИ МКС 2017. ГОДИНЕ
}

(Актуелни теоријско-методолошки проблеми проучавања и наставе словенских језика, књижевности и култура: зборник радова, Међународна научна конференција Комисије за наставу словенских језика и књижевности Међународног комитета слависта, Београд: Филолошки факултет, 2018.)

Зборник радова Актуелни теоријско-методолошки проблеми проучавања и наставе словенских језика, књижевности и култура доноси 19 радова изложених на Међународној научној конференцији Комисије за наставу словенских језика и књижевности Међународног комитета слависта, одржаној у јуну 2017. године на Филолошком факултету Универзитета у Београду. Публикација обједињује осам радова који тематизују питања наставе књижевности и једанаест радова који тематизују различите области наставе језика. Сви реферати баве се питањима књижевности, језика и културе у наставном контексту - на основношколском, средњошколском и универзитетском нивоу. Уредник зборника и предсједник комисије, проф. др Љиљана Бајић, у уводнику зборника наводи као циљеве рада Комисије, а самим тим и овог конкретног издања, оснаживање интересовања и мотивације научних радника за ову комплексну, али изузетно значајну област славистичких проучавања: „Разумевање наставе као 
приоритетног подручја научног рада, посебно њене дисперзивности и сложености, која се у савременом свету доводи у везу са различитим образовним политикама, омогућило је да се на међународној конференцији разложно нађе значајан број тема и да се оне представе у овом зборнику".

У раду Књижевни текст и настава словенских језика Љиљана Бајић актуелизује питање значаја књижевног текста у настави страних језика. Она дефинише изучавање словенских језика кроз три различита вида: као матерњих, инословенских и страних, при чему посебан акценат ставља на могућности компаративног приступа књижевним текстовима из различитих словенских књижевности у иноловенском културном контексту. На примјеру рецепције Гогољеве комедије Ревизор и Нушићевог Сумњивог лица показано је на који начин поредбени приступ двама словенским текстовима може додатно да освијетли различите језичке, стилске, тематолошке и културолошке елементе књижевних дјела. Посебна пажња посвећена је хумору, односно смијеху у Гогољевом и Нушићевом дјелу, чиме се указује на поетичке разлике и сличности, али и показује значај корелативног становишта у вези са изучавањем уплива појава и међусобних утицаја у књижевним дјелима. Овакав приступ илуструје се на примјеру поредбеног изучавања дјела Достојевског и Боре Станковића, кроз тумачење теме биједних људи у дјелу двају писаца. Ауторка закључује да тематско-мотивски слој који се актуелизује има сличан извор код оба писца - сиромаштво, манијакална тематика, страсти које се граниче са лудилом, болест, на једној, и хуманистички став разумевања и симпатије за предочени свет, на другој страни, што подразумева перцепцију јунака као посебних и ванредно вредних припадника друштвене заједнице, иако врло често бивају маргинализовани.

Наталија Берницка у свом раду доноси преглед историје наставе словенских језика у Француској. Ауторка наводи како је до 1840. године наставно изучавање словенских језика у Француској било спорадично и заснивало се на ентузијазму појединаца. Својеврсну прекретницу представља оснивање Катедре словенскиих језика и књижевности на Француском колеџу (Collège de 
France), и то, симптоматично, усљед руско-пољских сукоба и захваљујући ангажовању истакнутог пољског слависте Адама Мицкијевича. Године 1868, на Сорбони, Луи Леже је одбранио прву славистичку докторску дисертацију, а 1876. године постаје шеф новоосноване катедре руског и српског језика при Школи источних језика. Након Првог свјетског рата, на иницијативу истакнутих слависта, у Паризу се оснива Институт за словенске језике, а нове катедре на којима се изучавају словенски језици, књижевности и културе отварају се широм земље. У наставну праксу постепено се, осим руског, уводе и пољски, чешки, српскохрватски и бугарски језик. Значајан посао на успостављању француске славистике у првој половини 20. вијека обавили су Ернест Деније, Антоан Меје и Пол Буаје. Након савезничке побједе над фашизмом у Другом свјетском рату, Совјетски савез и руски језик наново добијају на популарности, па се од 1947. руски предаје у средњим, а од 1955. године у основним школама у Француској. Усљед политичке ситуације крајем 20. вијека, руски језик поново губи на популарности у француској средини, иако је и данас, у односу на све остале словенске језике и њихово изучавање, у најбољем положају. Ипак, Наталија Берницка свој реферат завршава у позитивном духу, наглашавајући како Асоцијација француских слависта, Институт словенских наука, различити културни центри, предавачи и језички ентузијасти интензивно раде на томе да словенским језицима побољшају статус.

У раду Објашњење непознатих ријечи при обради књижевног текста Вељко Брборић скреће пажњу на све мањи лексички фонд којим владају ученици основних и средњих школа, те на важност проширења њиховог језичког богатства у наставном процесу. Аутор даје кратак преглед тумачења непознатих ријечи као методичке радње у избору литературе, те констатује како би употреба рјечника на часовима српског језика морала бити заступљена у свим школама и на свим нивоима образовања. Брборић такође наглашава чињеницу да је велики недостатак у овој области то што још увијек не постоји адекватан школски рјечник. У другом дијелу рада аутор скреће пажњу на пропусте које је маркирао у актуелним основношколским и средњошколским 
читанкама, указујући на честу појаву тумачења непознате ријечи синонимичном ријечју (која често бива такође непозната ученицама) или конструкцијама које не дају довољно описних квалитета појма који се објашњава. Он такође скреће пажњу на неуједначеност објашњења која се појављују у појединим уџбеницима, те на ситуације у којима се аутори уџбеника опредјељују за тумачење само оног значења које одређена ријеч има у датом контексту, док остала значења не наводе.

Божа Кракар Вогел у свом раду бавила се промјенама у настави књижевности у Словенији, у посљедњим деценијама. Она је подсјетила на промјене у плановима и програмима југословенских република које су започете 80 -их година прошлог вијека, а које су се темељиле на уједначавању броја књижевних дјела из свих република у школским програмима, како би ученици упознавали не само своју „уско националну” литературу, него и књижевност свих народа Југославије. Паралелно са овим промјенама, критичари словеначког наставног програма указују на недостатке који произилазе из претежно позитивистичког и фактографског приступа у настави књижевности. Такође, у раду се наводе негативне реакције јавности поводом увођења екстерне матуре 1995. године. Есеј, који је уведен као испитна форма, управо да би се направио отклон од формалистичког приступа књижевности и ученици навели да критички промишљају и интерпретирају књижевна дјела, изазвао је дискусије на тему подобности есеја као облика израза за ученике средње школе. Свеобухватна курикуларна промјена 1998. године донијела је промјене у форми и садржају наставних програма. Као једна од најзначајнијих новина уведено је деветогодишње основно образовање, а у вези са новим програмом матерњег језика и књижевности констатује се да је у односу на ранијих $20 \%$, са колико су била заступљена дјела аутора свих југословенских књижевности, сада тај број драстично смањен, јер оне више нису убројане у посебну категорију, него припојене свјетској књижевности. Овом курикуларном промјеном није претрпјела једино руска књижевност, која је и даље заступљена великим бројем дјела и аутора, али су све остале (југо)словенске књижевности сведене на изузетно мали 
број дјела/аутора. Рецепцијско-комуникацијска дидактика књижевности, како је ауторка назива, такође није донијела очекиване резултате, будући да је тежњом да се ученици у што већој мјери ослободе фактографије, избор аутора и дјела за проучавање (у средњој школи) окрњен на оно најнужније. Идућа реформа донијела је примјену системско-комуникацијске дидактике књижевности, која се заснивала на књижевном систему и смјештању књижевних дјела у контекст. Божа Кракар Вогел закључује како овај приступ показује најбоље резултате у гимназијском образовању, док је за основну школу примјеренији рецепцијско-комуникацијски приступ.

На почетку свог рада Фонетски стереотипи и уцбеници руског језика у Србији Јелена Гинић даје објашњење и преглед артикулационе базе руског језика, те скреће пажњу на неке њене особености које су говорницима српског језика посебно изазовне за усвајање. У наставку рада даје се преглед фонетског материјала у уџбеничким комплетима за основну школу. Након опсежне квантитативне и квалитативне анализе, између осталог, долази се до закључка да су у свим уџбеницима сегментне доминанте заступљеније од прозодијских, те да је у већини уџбеника недовољно пажње посвећено парним тврдим и меким сугласницима, односно звучним и безвучним гласовима. У поређењу са уџбеничким комплетима који су били у употреби шездесетих и седамдесетих година, ауторка долази до закључка да се опозицији тврд/ мек глас недовољно пажње посвећује у обје генерације уџбеника, иако би она требало да буде централна доминантна наставе фонетике. Такође, у обје генерације уџбеника најучесталије се појављују гласови [ч'], [j], [ш'], [ж], [ш], [ц], [л] и [ы], што представља фонетски стереотип, како ауторка наводи, будући да је њен став да поменуте доминанте ни ком случају не треба да представљају централно мјесто у настави фонетике.

Нина Говедар се у свом раду бавила наратолошким приступом роману Проклета авлија у универзитетској, те могућностима интерпретације у средњошколској настави. На самом почетку рада скреће се пажња на савремене концепте књижевне теорије и неопходност њихове примјене у универзитетској настави. Из- 
двајају се могућности ваљаног мотивисања студената за читање и тумачење овог књижевног текста, уз неопходне сугестије у вези са теоријским оквиром који ће при интерпретацији бити коришћен. У наставку рада даје се преглед најзначајнијих ставова и одлика когнитивне наратологије у одлосу на класичну, да би се затим приступило анализи наративности у роману Проклета авлија. Наративна уланчавања која су карактеристична за овај роман, посматрају се из перспективе потенцијалне виртуелности, односно потенцијала виртуелног. Скреће се пажња на чињеницу да виртуелне реалности постоје у свим наративима започетим у роману (фра Петрово, Заимово, Хаимово и Ђамилово причање). Даље у раду актуелизује се феномен односа простора и времена, односно постојања два паралелна временска тока - једног реалног, стварносног, ког свако мало обиљежи откуцај часовника, и са друге стране вријеме које сраста с митом и које омогућава Ћамилу да урони у сопствену приповијест и изједначи се са Џем Султаном. У другом дијелу рада наводе се могућности средњошколске наставне интерпретације романа Проклета авлија, при чему је посебна пажња посвећена формулисању наставних циљева које интерпретацијом треба остварити, те моделовању задатака за истраживачко читање, који ће ученицима служити као водич при тумачењу романа.

Мирјана Костић Голубичић писала је о раду на усавршавању изговора студената београдске полонистике. У првом дијелу наводе се подаци о историји и развоју београдске полонистике, те о уоченим интерференцијама при учењу нових словенских језика код матерњих говорника неког словенског језика. Будући да се ове интерференције јављају и код говорника српског језика који почињу да уче пољски, у раду се наводе неки конкретни примјери „језичких сукоба”. У наставку рада даје се преглед изговора пољских назала и карактеристика самогласника, те карактеристика сугласника, што прати образложење о значају прозодије у изговору пољских гласова. Ауторка даје и илустративан преглед вјежбања која се користе како би студенти што боље и што ефикасније савладали фонацијски и артикулационо-акустички систем новог језика. На крају рада се истиче како најмање проблема 
са усвајањем и увјежбавањем изговора имају студенти који имају изражен музички и језички слух, али како је за потпуно савладавање пољског изговора увијек неопходан стрпљив системски рад.

Подстакнута сарадничким искуством на предмету који се бави корелацијом интернета и књижевности у настави, Мина Ђурић у свом раду пише о могућностима приручника за интернет и књижевност у настави. Ауторка наводи да би потенцијални пруручник требало да садржи рјечник или појмовник, уз хрестоматију критичких и есејистичких погледа да назначену тему, као и препоручени избор из веблиографије. Као важан сегмент приступа овој комплексној теми, ауторка издваја значај образлагања друштвених, технолошких и културолошких упоришта, као и књижевнотеоријске условљености одређених одлика литературе дигиталног модернизма. У оквиру мултимодалног читања као посебно важна издваја тенуто и вортекс читања, која види и као могућу парадигму за проналажење одговара на питање који ће од екстремних аспеката дигиталног модернизма постати канонски елемент. Констатује се како литература дигиталног модернизма, усљед продуктивог дијалога са (пост)модернистичким дјелима, подразумијева и образац текстуалног трансфера. Закључак је, свакако, да идеје до којих доводи настава посвећена корелацији књижевности и интернета представљају изразито актуелан теоријско-методолошки правац истраживања.

Рад Милене Ивановић говори о принципима организовања граматичког материјала у почетној настави граматике украјинског језика. На самом почетку рада ауторка нас уводи у систем обучавања студената украјинистике у оквиру двају различитих предмета - Украјински језик (теоријско познавање језичког система стандардног украјинског језика, компаративно и контрастивно изучавање украјинског и српског језика) и Савремени украјински језик (усвајање и развијање језичких умијења и вјештина, стицање одговарајуће језичке компетенције). Ивановић наводи како су за наставу граматике изузетно важни функционални и комуникативни принцип, који студенте доводе до стицања не само граматичких него и семантичких компетенција, као и стицања практичних језичких вјештина. У другом дијелу 
рада посебно се наглашава значај контрастивних граматичких истраживања за најбоље резулате при учењу језика, те се даје преглед усвајања украјинског падежног система у односу на српски. Ауторка закључује како се овај начин организације градива показао као најефикаснији, те како захваљујући комбинацији неколиких принципа, те коришћењем позитивног трасфера студенти брзо и успјешно савладавају граматичке основе украјинског језика.

У уводном дијелу рада Бројевне речи у настави српског језика: актуелно стање и проблеми, Валентина Илић се бави недосљедношћу у граматичким приручницима када је у питању подјела и именовање бројевних ријечи. Она наводи традиционалну трочлану подјелу на основне, редне и збирне, односно модерну бинарну подјелу на основне и редне (збирни се сврставају у категорију основних). Такође, скреће се пажња на флексибилност терминологије (бројне ријечи, бројне именище - бројевне ријечи, бројевне именице). Као циљ овога рада поставља се указивање на актуелне проблеме и недостатке у настави бројевних ријечи, те давање сугестије за њихово рјешавање. Закључује се како уџбеници ни за основну ни за средњу школу немају униформан приступ наставном програму, подјели и терминологији, што уноси додатне нејасноће и проблеме у наставни процес. У другом дијелу рада доносе се резултати истраживања ученичког познавања бројевних ријечи (именовање, класификација, граматика и употреба), а резултати су показали да ученици најслабије владају збирним бројевима, као и да је знање о употреби бројевних ријечи ниско, што доприноси и грешкама у правопису. Приједлог ауторке је да се ученицима подробно објасне граматичка обиљежја која бројевну именицу чине именицом, те семантичка која је чине бројем, како би им се појасиле прелазне форме и њихово мјесто у језичком систему.

Теолингвистички приступ настави словенских језика (на материјалу лексике и фразеологије руског и српског језика) рад је Ксеније Кончаревић који представља наставне могућности једне од новијих парадигми у славистици. Теолингвистика омогућава онима који уче страни језик да боље разумију структуру и функ- 
ционисање језичких јединица у контексту културе сакралног. Ауторка издваја значај теолингвистичког коментара при обради лексике из домена религије и духовности, те широк инвентар теонема на фразеолошком нивоу. Наводи да је примарни задатак фразеологије семантизовање лексема на основу теолошких и других релевантних знања, те да је уз помоћ фразеолошког фонда могуће препознати и стереотипе везане за духовну сферу. На примјеру контрастивног приступа српском и руском језику, Кончаревић, на основу концепције Ј. П. Солодуба, успоставља класификацију у којој се издвајају међујезички фразеолошки еквиваленти, међујезички фразеолошки адеквати са истовјетном семантиком и блиском прототипском основом, међујезички фразеолошки адеквати са истовјетом семантиком и различитом прототипском организацијом, те псеудоеквиваленти (са различитом семантиком и блиском или истовјетном прототипском организацијом). Ауторка закључује како су лексеме и фраземи са сакралном тематиком и религијском компонентом значења захвалан објект теолингвистичке презентације у настави.

Рад Српски као страни језик и српски као нематерњи - сличности и разлике Весне Крајишник, доноси преглед специфичности које настава српског као нематерњег језика подразумијева у пракси. Док законски оквир подразумијева исти наставни програм за све ученике српског језика као нематерњег, ауторка у раду показује да је ситуација у пракси далеко комплекснија. Први проблем који ауторка наводи у вези са извођењем наставе овог предмета јесте питање да ли ученици долазе из језички хомогених или хетерогених средина, односно, какво је њихово раније језичко искуство. Уколико ученици одрастају у језички хомогеним средима, или им је матерњи језик несродан српском језику, настава српског језика као нематерњег за њих се методички приближава настави српског као страног језика. Настава српског као нематерњег језика, у складу са новим Стандардима, као циљ представља разумијевање и способност примјене у писаној и говорној комуникацији, а не формално познавање граматичких правила. Закључује се како је с обзиром на различитост матерњих језика и специфично демографско окружење ученика, организовање и реализацију наставе 
српског језика као нематерњег потребно ускладити са бројним лингвистичким, социјалним и културолошким аспектима.

Зона Мркаљ у свом раду Типови карактеризащије епских јунака у старијим разредима основне школе наводи како је, иако је тумачење књижевних ликова само један од елемената тумачења књижевног дјела у настави, разумијевање различитих типова јунака често кључни чинилац интерпретације. Ауторка наводи како је поступак карактеризације условљен природом дјела, те како њена природа зависи и од поетичких критеријума епохе. У раду се констатује и како је често у оквиру наставног процеса ученицима неопходно додатно разјаснити термине лик, јунак, карактер и тип. Такође, наводе се универзални и специфични елементи који утичу на формирање књижевног лика и његово тумачење - систем особина (унутрашњих, спољашњих, интерперсоналних, темперамент) и систем друштвеноистријских, културолошких, географских и других утицаја. Констатовано је како, иако се у уџбеницима прецизно наводе врсте карактеризације према општим и посебним особинама лика (физичка, психолошка, језичка, социјална и етичка), ученици, чак и на такмичарском нивоу, нису увијек у стању да препознају механизам карактеризације јунака, за шта се у раду наводе и конкретни примјери. Такође се указује на чињеницу да статичка карактеризација ликова, која инсистира на једној доминантној особина лика, ученицима помаже да поузданије разумијевају карактеризацију ликова у народној књижевности. Са друге стране, динамичка карактеризација, специфична за жанрове у којима се лик развија и сазријева, омогућава нам да боље разумијемо специфичности одређеног књижевног жанра. Закључак је да типови карактеризације, који су специфично градиво основне школе, касније у средњошколској настави ученицима омогућавају темељније разумијевање и тумачење књижевних дјела, те сублимирају свијест о композиционим, структурним или поетичким одликама умјетничких текстова.

У свом раду Модели преношења туђег говора у настави српског као страног језика, Милка Николић говори о значају усвајања основних, али и осталих модела синтаксичких конструкција туђег говора код оних који уче српски језик као страни. Ау- 
торка скреће пажњу на то да се основни модели управног и неуправног говора обрађују на средњем нивоу учења, те предлаже да се на напредном нивоу обрађују модели који настају њиховом модификацијом. У раду се даје преглед синтаксичког подсистема модела преношења туђег говора, односно низ критеријума на основу којих се могу описати сви модели преношења туђег говора. Наводи се приједлог методичког приступа кроз студентску анализу реалних примјера из корпуса, при чему акценат није на терминолошком познавању критеријума и модела, већ на њиховом препознавању и функционалној употреби. У складу са наведеним, Николић предлаже да се на напредном нивоу користе умјетнички текстови у којима преношење туђег говора представља стваралачки поступак. Слични приједлози дати су и за друге функционалне стилове, при чему се пажња скреће на чињеницу да овладавање примјеном различитих поступака у различитим стиловима помаже ученицима да овладају језичким компетенцијама на рецептивном и перцептивном плану.

Рад Идентибикација и њена ограничења у тумачењу књижевног текста (од претпостављеног до критичког читаоца) Зоране Опачић проблематизује дјетињство као конструкт који, заправо, граде одрасли аутори, пишући књижевност за дјецу. Она наводи недостатке универзалности дјетињства као теме, будући да су представе о дјетињству условљене широком скалом фактора. Савремена схватања о специфичној природи дјетета и потреби за осамостаљењем и развијањем кроз игру, навела су и савремене ауторе да конструшу свијет у коме је дијете у позицији да истражује, а приповиједање се, за разлику од традиционалне позиције у којој се поступци дјететета процјењују, препушта самом дјетету-јунаку. Друго важно питање које се у раду актуелизује јесте проблем идентификације са књижевним текстом и ликовима у њему, односно питање да ли је идентификација добар пут за разумијевање књижевног текста у младом узрасту. Млади читаоци се најлакше поистовјећују са главним јунацима, односно јунацима из чије се перспективе у дјелу приповиједа. Међутим, ауторка наводи негативну праксу у настави књижевности у млађем узрасту, гдје се идентификација са ликовима користи као 
пречица ка доживљавању и тумачењу књижевног текста, иако на тај начин ученике објективизујемо, умјесто да их подстичемо да развијају критичку дистанцу према тексту. На крају се закључује како, без обзира на позицију приповједача у дјелу и потенцијално (привидно) олакшану идентификацију, да би што потпуније схватио смисао и вишезначног књижевносг текста, (млади) читалац треба да чини управо супротно - да посматра слику умјетничког свијета из различитих перспектива.

Рад Марека Пјењонжека доноси преглед реформе образовног система у Пољској у посљедњих петнаест година, те проблематизује концепцију језичке политике из перспективе културне перформатике. Аутор указује на чињеницу да је образовни систем у том контексту неодвојив од друштвене парадигме из које произилази, те да је немогуће посматрати га изолованог из контекста актуелних политичких и друштвених појава попут глобализације, миграција и BREXIT-a. Као један од највећих проблема који су проистекли из споменутих курикуларних реформи, аутор наводи увођење велике матуре и паралелно укидање пријемних испита на високошколским установама. Ауторове замјерке на ове промјене тичу се чињенице да се хуманистичко образовање обликује у складу са потребама друштених политика, те да се и употреба језика и образовање инструментализују.

У свом раду Реализам протумачен деци: постмодерно и реално у роману Опсада цркве Св. Спаса Горана Петровића Александра Секулић пише о историји и причи, односно реалном и постмодерном, који се у роману преплићу поетичким укрштањем књижевних традиција, умјетничко-стилских поступака, облика приповиједања и жанрова. Ауторка наглашава проблематизовање историје саме у историјској постмодернистичкој прози, те поставља питање како реалном, које се као парафраза историје јавља у Петровићевом роману, методолошки приступити. Једно од кључних питања која се у раду отврају јесте тумачење проблемског мјеста у роману, колизије приче и Историје. Закључује се да адекватним методолошким вођењем, тумачење романа Onсада иркве Св. Спаса пружа могућности разумијевања и проблематизације различитих аспеката постмодернизма, те нарочито његовог односа према историји и фикцији. 
Драгана Вељковић Станковић у раду Човек у великом кругу постојања - когнитивни приступ у раду лингвистичке секције констатује како се у методичкој литератури не налази довољно материјала нити модела који би олакшали и подстицали рад у лингвистичкој секцији, те се овај рад у великом броју школа најчешће своди на припремање неколико ученика за такмичења. На овај начин, ученицима се не пружа довољно прилика за самостално истраживање материје и усвајање нових знања, те се ауторка залаже за паралелно унапређивање знања из језика и изграђивање вокабулара, тј. интегративни приступ са што већим потенцијалом за интерпредметну и међупредметну корелацију. У наставку рада, Вељковић Станковић скицира конкретан модел рада лингвистичке секције, темељен на методологији примијењене когнитивне лингвистике, при чему му је тежиште на упознавању и откривању начина настанка лексема везаних за метафору великог ланца постојања, тј. великог круга (зоолексеме, фитолексеме, ријечи које денотирају ствари, а односе се на човјека и људско). Примарни циљ оваквог методичког поступања, наводи ауторка, јесте да ученици освијесте механизам дјеловања појмовних метафора, али и да боље упознају механизам лексичке метафоре. Ауторка закључује како је због своје тематске универзалности, овакав приступ и образовно и васпитно значајан, те да га је потребно укључити не само у рад лингвистичких секција, него и у редовне програмске садржаје наставе српског језика и књижевности.

На почетку рада Наташе Станковић Шошо Методичка гледишта на хумористичку прозу Бранислава Нушића истиче се значај хумора у настави као подстицаја за читање и тумачење књижевних дјела, при чему се пажња скреће на ученичку перцепцију и разумијевање Нушићевог хумора, којим се разоткривају бројне друштвене мањкавости. Наводи се како Нушићеви текстови код ученика подстичу интересовање за друштвену стварност, личне и етичке проблеме и развијају моралну свијест и критички став, чиме ученици усвајају значајне важне животне истине и уче како да ваљано морално поступају. Ауторка такође истиче како смијех, односно хумор у књижевним дјелима може бити изузетно подстицајан за ученичко стваралаштво. Напријед наведено у 
раду се показује на примјеру наставне обраде Нушићеве кратке приче Лек од љубави, која, захваљујући својој једноставности и занимљивости, како наводи ауторка, пружа могућност ученицима различитих узраста основне школе да у њеном читању и тумачењу уживају. Станковић Шошо на крају закључује како је Нyшићев смијех, који има функцију разоткривања и подсмијавања људским манама и друштвеним девијацијама, и који је по својој природи исцјелитељски, оно што Нушића издваја као врсног комедиографа.

Имајући у виду тематску разноликост и ширину обрађених теоријско-методолошких проблема у наставном контексту, те чињеницу да сабира текстове који се наставом словенских језика, књижевности и култура баве на свим нивоима образовања (иако првенствено на универзитетском), нема сумње да овај зборник представља изузетно важан допринос методици наставе за цјелокупан славистички свијет. Вјерујемо да је овај зборник значајан допринос остваривању циља који је Комисија за наставу словенских језика и књижевности Међународног комитета слависта пред себе поставила - унапређењу научноистраживачког рада у домену наставе, те развијању научних и наставних компетенција истраживача у овој области. 